\title{
Employee Retention Factors: The Case of Hotels in Cape Town, South Africa
}

\author{
Ikechukwu O. Ezeuduji*, Thandokazi Lulu Mbane \\ University of Zululand, South Africa \\ Cape Peninsula University of Technology, South Africa \\ Ezeudujil@unizulu.ac.za*, ezeuduji3@yahoo.com
}

\begin{abstract}
High turnover of employees in the hotel sector has been widely reported in academic papers. This high turnover has associated costs, such as financial costs, inconsistency in delivering service quality, and probable loss of customer loyalty. This empirical study investigates hotel employees' responses to statements that relate to work conditions that support employee retention. Selected three, four and five star hotels in Cape Town, South Africa participated in this study. A structured respondent-completed questionnaire was used to collect data that were subjected to descriptive, bivariate and multivariate analyses. Result highlights suggest that hotel employees, dominated by the female population, are mostly not so desperate to leave their employment soon, however not many of them have worked in the hotel for more than five years. There are positive inter-correlations among 'employee retention' factor and other factors that relate to work conditions that support employee retention (compensation, employee development, work engagement, work relations, and working hours). Results also show that 'strict supervision', 'long working hours' and 'perceived unfair salary' are the top major concerns for hotel employees. These findings will enable hotel employers address employee concerns in order to curb the high employee turnover costs. Possible comparative research in other nations and continents will help establish cultural similarities and differences among nations or continents.
\end{abstract}

Keywords: Employee retention, employee turnover, Cape Town hotels, hotel sector, sub-Saharan Africa

\section{Introduction}

Employee retention in the hotel sector has been a major concern, as several studies have reported high employee turnover in hotels (such as Davidson \& Wang, 2011; Mohsin, Lengler \& Kumar, 2013; Pearlman \& Schaffer, 2013). Researchers (such as AlBattat, Som \& Halalat, 2014; Davidson \& Wang, 2011; Kuria, Alice \& Wanderi, 2012; Mohanty \& Mohanty, 2014) attributed the cause of this reported high employee turnover in hotels to be among others: employees' perception of their salaries and benefits being unfair compared with their responsibilities; minimal employee development opportunities; insufficient job involvement or work engagement; poor work relationships between managers and subordinates; and long working hours. High employee turnover has associated costs, such as financial costs (when hotels will have to replace employees), inconsistency in delivering service quality (as the performance of different employees vary), and the likely subsequent loss in customer loyalty (Kuria et al., 2012; Mohanty \& Mohanty, 2014; Yam \& Raybould, 2011; Yang, Wan \& Fu, 2012).In as much as there is much international research on hotel employee retention, the situation in Africa, especially sub-Saharan Africa is not well reported. Mohsin et al. (2013) posit that hotel employee turnover is a global problem, not particular to any given nation. This research explores the relationships between and among employee retention and related work conditions factors that support employee retention in hotels operating in Cape Town, South Africa. It also seeks to explain which variables may support or deter employee retention in the hotel sector, and also check if there are socio-demographic differences among employees regarding how they perceive hotel employment or their willingness to remain in this employment for a long time. South Africa is a highly diverse nation in terms of cultural groups who are South Africans and those who live and work in South Africa. It is usual to classify employees in South Africa, not only as females or males, but also as Black, White, Coloured, Indian and Asian. These cultural groups may also perceive hotel employment and the working conditions differently. The findings of this study will help hotel employers to address employee concerns so as to reduce the high employee turnover costs. It is envisaged that possible comparative research in other nations and continents will help establish cultural similarities and differences among nations or continents. Cape Town is globally renowned as a 'must visit' tourism destination. There are so many hotels of different grades in Cape Town, but this study focuses on three, four and five star hotels, which are relatively larger, have more employees, and likely to employ nonfamily members in relation to one or two star hotels. The theoretical background of this study is built on literature review of previous academic articles. 


\section{Literature Review}

As stated in the introduction, previous studies pointed at the causes of high employee turnover in hotels to be among others: employees' perception of their salaries and benefits being unfair compared with their responsibilities; minimal employee development opportunities; insufficient job involvement or work engagement; poor work relationships between managers and subordinates; and long working hours (such as AlBattat, Som \& Halalat, 2014; Davidson \& Wang, 2011; Kuria, Alice \& Wanderi, 2012; Mohanty \& Mohanty, 2014).

Compensation: Permarupan, Saufi and Mahmud (2013) stated that career is important in life, and employment provides individual with a better sense of purpose, challenges, self-fulfilment and compensation. Nasurdin, Ahmad and Tan (2015) posit compensation as extrinsic rewards which employees receive in exchange for their employment, such as basic salary, incentives or bonuses. Nasurdinet al. (2015) further state that monetary rewards are very relevant to especially frontline service staff working in hotels because these positions are normally associated with low wage and minimal tangible rewards, though working long hours is expected of frontline employees. When employees perceive their salary to be fair, they will make every effort to deliver proper service (Wu, Sturman \& Wang, 2013). Fair pay is perceived to improve employee job engagement, and at the same time, decrease job withdrawal (Jung \& Yoon, 2015).Till and Karren (2011) therefore stated that pay satisfaction is arguably a function of the difference between perceived pay level and the employees' perception of how much their pay should be. Hence pay satisfaction is determined by fairness of pay and comparison of pay. When employees feel that they are paid fairly, they will be more motivated to deliver higher performance to the organisation than the employees who perceive they are not paid fairly (Ford, Sturman \& Heaton, 2012). Employees who feel that promotion opportunities, fair pay and better working hours are lacking in an organisation, are very likely to withdraw their employment (Yang et al., 2012). Wu et al. (2013) posit that where there is no fair compensation system, it is very likely that even a great employee selection system will subsequently fail. Management, therefore, should build reward structures that can attract and retain employees (Mohanty \& Mohanty, 2014), especially the talented ones.

Employee Development: Part of management's responsibility is to select, employ, develop and promote their employees, therefore management engage with employees to perform their skills audit and provide development plans, such as coaching, mentoring, and managing individual development programmes (Cloete \& Allen-Payne, 2012).Employees expect organizational support and opportunities for growth from their employer institutions, however Kong, Cheung and Song (2012)posit that organizations now expect individual employees to steer their own career development and management. Kong et al. (2012) did not encourage this but admonish organisations to take care of their employees' career management. Human resource managers try to understand the employees' career interest, capabilities and needs (Yang et al.,2012).Baum (2012) relating this to tourism establishments, states that managing and developing employees is a critical function that determines the performance or competitive level of tourism businesses. Nasurdinet al. (2015) argue that employee development in form of training activities does influence employee performance in twofold: (a) the skills and abilities that are relevant to employees' job description and development, leading to greater job performance, and (b) employees' satisfaction and many other positive job-related attitudes, leading to greater show of positive behaviours. Chen and Wallace (2011) have posited that multi-skilling of workers is one of the major ways to increase productivity, so that employees can better fill-in each other's positions when they are unavailable. For employees to benefit from any form of a development program, they should be interested in it and endeavor to participate in it, when given the chance.

Work Engagement: Employees have to be trained first on their jobs, and then be motivated to perform their jobs optimally (Ford et al., 2012). Employees need to be fully involved in their places of work, when possible. Zopiatis, Constanti and Theocharous (2014) discuss employee work involvement as an active participation in employee's job, enabling employees to make work-related decisions. Permarupan et al. (2013) suggest that employees' high work involvement may lead to job satisfaction, increased work outputs and enhanced loyalty to the organisation. Karatepe and Ngeche (2012) did say that engaged employees are known to have high levels of energy, are excited in their job and are mostly absorbed in their work. They (Karatepe \& Ngeche) 
went further to posit that work engagement does lead to excellent performance in the workplace. However Zopiatis et al. (2014) view work involvement as being strongly more related toorganisational commitment than job satisfaction. Chen and Wallace (2011) went further to conclude that employee engagement improves employee productivity and organization's international competitiveness as it does develop the skills and capabilities of workers.

Work relationships: In as much as working with hotel guests can be challenging or difficult, tensions among employees are more evident that tensions that are associated to guests (O'Neill \& Davis, 2011). Problems among employees thus have more negative impact on hotel employees' emotion and health than problems with guests(O'Neill and Davis, 2011).High cooperation and related interaction among managers, subordinates, and work colleagues are very important for the hospitality industry (Lee, Teng and Chen, 2015). Solnet, Kralj and Kandampully (2012) advised hospitality managers or owners to constantly enhance the working environment of their workers as this has a direct link to many desirable organisational outcomes, such as customer satisfaction, profitability, and customer loyalty. Working in any organisation requires specific rules to be adhered to (Lam \& Chen, 2012). The work culture in hotels involves teamwork, cooperation among team members as well as coaching and mentoring relations that can uproot role ambiguity or role conflict (Kim, Im \& Wang, 2015).Employees who have better relationship with the manager may tend to receive preferential treatment, growth opportunities and more intensive support than others who are not (Lee et al., 2015). Favouritism is shunned at in every workplace, as employees constantly demand equity and fairness from managers.

Working hours: Long working hours are said to be among the factors that lead to high employee turnover in hotels. Mohsin et al. (2013) posit that the amount and nature of work expected, scheduled working hours, accompanying job pressures and stress in employee's personal life have impacts on employees' intention to leave the hotel. Stress inhotel employment is often exacerbated by long and irregular working hours, poor job design and role distribution, insufficient training and employee development, excessive workloads, and poor management (McNamara, Bohle \& Quinlan, 2011). Also McNamara et al. posit that temporary employees experience lower stress levels than permanent employees. Employee's intention to withdraw his or her employment in a hotel due to long working hours is highly arguable, as working long hours in the hospitality industry is seen as one of the many conditions of the hospitality industry. Long and antisocial working hours are inadvertently among the conditions that are associated with hospitality work environment (Davidson \& Wang, 2011). Hwang, Lee, Chang \& Kim(2014)concur that some of the common occupational stresses experienced by hotel employees are long working hours and heavy workloads. Davidson and Wang (2011) maintain that hotel sector employees are often not compensated for their long working hours. The next section addresses how the data for this study were collected and analysed.

\section{Methodology}

The nature of the tourism and hospitality research requires much quantified data to arrive at conclusions (Ezeuduji, 2013; Ezeuduji \& de Jager, 2015; Veal, 2011). This study used respondent-completed structured questionnaire survey to obtain data that were analyzed for information on employee retention and related factors. Most of the questions were close-ended and the responses scaled as ordinal variables. Employee retention and related factors' variables were measured along a 5-point Likert Scale (1 to 5; strongly agree to strongly disagree). Other variables are categorical or nominal in nature (employee profile).Questionnaire variables emanated from literature review done. Literature on employee retention or employee turnover identified factors related to employee retention (Jung \& Yoon, 2015; Mohsin et al., 2013; Wells \&Welty Peachey, 2011); namely employee development(Jung \& Yoon, 2015; Kong et al, 2012), compensation (Hong, Hao, Kumar, Ramendran, \& Kadiresan, 2012; Jung \& Yoon, 2015), work relations (Lee, Teng \& Chen, 2015; O’Neill \& Davis, 2011), work engagement (Hong et al., 2012; Jung \& Yoon, 2015; Karatepe \& Ngeche, 2012), and working hours (Davidson \& Wang, 2011; Hon, Chan \& Lu, 2013; Mohanty \& Mohanty, 2014).

A non-probabilistic sampling approach (convenience sampling) was used for this research to recruit respondents from three, four and five star hotels operating in Cape Town. These hotels identified their interest to participate in this research. Within these hotels, 217 employees were randomly surveyed, and from these, 210 returned questionnaires were found usable for data analysis. IBM's statistics software was 
used for data analysis (IBM Corporation, 2016). First stage of analyses used descriptive analysis (frequencies) for all variables, followed by the second stage of analyses using multivariate analysis (reliability tests) of employee retention variables and related factors' variables. Reliability tests were done to check for internal consistencies among variables used to explain particular factors. The third stage of analyses used correlation test (Spearman's - as all variables were found not normally distributed) to check for relationships among employee retention factor and related factors (compensation, employee development, work engagement, work relations, and working hours). Veal (2011) supported the use of Correlation test to explore relationships between ordinal and/or ranked variables. This study accepted relationships between variables at $99 \%$ confidence interval.

Cronbach's Alpha coefficient is used in the reliability tests to predict internal consistency among variables explaining a particular factor (Cortina, 1993; Gliem \& Gliem, 2003). The authors Gliem and Gliem (2003) posit that Cronbach Alpha's reliability coefficient does range between 0 to1. The benchmark score to use to determine adequate internal consistency among variables explaining a particular factor has been much debated (authors such as George \& Mallery, 2003; Gliem \& Gliem, 2003; Nunally, 1978).In as much as George and Mallery (2003) advocated the use of Cronbach's Alpha coefficient of between 0.5 and 0.7 to explain adequate consistency; Tavakol and Dennick (2011) posit that low Cronbach's Alpha scores might result when few variables are being used to explain a factor or when there is a weak interrelation among variables that are being used in the analysis. For this study's reliability analyses, a Cronbach Alpha score of 0.6 or above was accepted owing to the relatively few numbers of variables that were used in each factor (employee retention, compensation, employee development, work engagement, work relations, and working hours). Subsequently, at the fourth stage of analyses, a Pearson Chi-Square test was conducted between employee retention and related variables (recoded into categorical variables) on the one hand and the employees' socio-demographic variables (also categorical), on the other hand (see Veal, 2011). This test was done at 95\% confidence interval. The next section discusses the findings of this study.

\section{Results and Discussion}

Employee Profile: Results from the hotel employee respondents show that females dominate males, and close to $60 \%$ of hotel staff is relatively young in age (less than 36 years old). Black and Coloured employees make up more than $71 \%$ of the sample, and close to $50 \%$ of the employees have no higher than a high school education (Table 1).

Table 1: Profile of the respondents $(n=210)$

\begin{tabular}{lll}
\hline Variable & Category & Frequency (\%) \\
\hline Gender & Female & 63.8 \\
Age group & Male & 36.2 \\
& $18-25$ years old & 16.7 \\
& $26-35$ years old & 41.4 \\
& $36-45$ years old & 30.5 \\
& $46-55$ years old & 8.6 \\
Cultural group & $56-65$ years old & 2.4 \\
& $65+$ years old & 0.4 \\
& Black & 35.7 \\
& Coloured & 35.2 \\
Highest level of education & Indian & 5.2 \\
attained & Asian & 1.4 \\
& White & 13.0 \\
Number of years working & 9.5 \\
in hotel & College & 46.7 \\
& University national diploma or first degree & 25.2 \\
& University Master's degree or above & 26.7 \\
& 6- -5 years & 1.4 \\
& 6 10 years & 63.6 \\
\hline
\end{tabular}




\begin{tabular}{|c|c|c|}
\hline \multirow{3}{*}{ Current department } & 10 years and above & 16.9 \\
\hline & $\begin{array}{l}\text { Food \& Beverage- food production/food services/room } \\
\text { service/convention \& catering }\end{array}$ & 20.5 \\
\hline & Rooms- reservations/front office/housekeeping/laundry & 45.2 \\
\hline \multirow{11}{*}{ Current position } & Personnel- employee relations/recruitment/training & 7.6 \\
\hline & Finance / accounting & 6.7 \\
\hline & Marketing and sales- sales & 4.8 \\
\hline & Maintenance \& Security - maintenance / security & 9.5 \\
\hline & Other ${ }^{1}$ & 5.7 \\
\hline & $\begin{array}{l}\text { First line } \quad \text { staff- } \\
\text { service/concierge/valet/waiter/waitress/counter } \\
\text { reception }\end{array}$ & 41.0 \\
\hline & Grassroots leader or supervisor & 13.7 \\
\hline & Unit chief (deputy manager or manager) & 6.7 \\
\hline & Department supervisor & 11.0 \\
\hline & General manager & 1.4 \\
\hline & Other ${ }^{2}$ & 26.2 \\
\hline
\end{tabular}

1'Other' here denotes managerial staff and staff in specialised units such as Spa and games

${ }^{2}$ 'other' here denotes managerial staff and staff in specialised units such as Human Resource, Spa, Accounts, Kitchen, Maintenance, Housekeeping and Security.

About $64 \%$ have not worked in the hotel for more than 5 years, and majority of the employees surveyed are working in the rooms, food and beverage, convention and catering sections.

Employee Retention Factors: From Table 2 results, it can be deduced that hotel employees agreed favourably to most of the employee retention and related factors' statements, however hotel employees raised serious concerns towards 'strict supervision' (about 46\%), 'long working hours being a problem' (about 34\%) and 'perceived unfair salary in relation to responsibilities' (about 34\%) as clear demotivating factors. Good news for hotel managers lie in the results that about $67 \%$ of the hotel employees disagreed that 'they cannot wait to leave the hotel', about $63 \%$ of them 'feel attached to the hotel', and about $42 \%$ 'want to remain in the hotel for a long time'.

Table 2: Employees' level of agreement to employee retention statements $(n=210)$

\begin{tabular}{|c|c|c|c|c|c|}
\hline Statements & $\begin{array}{l}\text { Strongly } \\
\text { agree }\end{array}$ & Agree & Neutral & Disagree & $\begin{array}{l}\text { Strongly } \\
\text { disagree }\end{array}$ \\
\hline \multicolumn{6}{|l|}{1 Employee retention } \\
\hline 1.1 I feel attached to this hotel & 24.3 & 39.0 & 20.0 & 10.5 & 6.2 \\
\hline $\begin{array}{l}1.2 \text { It would be difficult for me to leave this } \\
\text { hotel }\end{array}$ & 14.8 & 23.8 & 32.4 & 18.6 & 10.4 \\
\hline $\begin{array}{l}1.3 \text { Working in this hotel is a labour of love } \\
\text { for me }\end{array}$ & 18.1 & 36.7 & 28.6 & 10.5 & 6.1 \\
\hline 1.4 It would be easy for me to leave this hotel & 9.1 & 22.5 & 30.1 & 23.4 & 14.9 \\
\hline $\begin{array}{l}1.5 \text { I want to remain in this hotel for a long } \\
\text { time }\end{array}$ & 20.0 & 22.4 & 26.7 & 19.0 & 11.9 \\
\hline 1.6 I cannot wait to leave this hotel & 8.2 & 5.8 & 18.8 & 33.6 & 33.6 \\
\hline \multicolumn{6}{|c|}{$\begin{array}{l}\text { Reliability Statistics (employee retention), Cronbach's Alpha }=.857, \mathbf{N} \text { of Items }=\mathbf{6} \\
\text { Valid cases }=207(98.6 \%), \text { Excluded cases }=3(1.4 \%), \text { Total }=210\end{array}$} \\
\hline \multicolumn{6}{|l|}{2 Compensation } \\
\hline $\begin{array}{l}2.1 \text { The amount of pay I receive in this hotel is } \\
\text { the industry wage for my position }\end{array}$ & 15.2 & 42.8 & 21.0 & 11.0 & 10.0 \\
\hline $\begin{array}{l}2.2 \text { My monthly salary in this hotel is not } \\
\text { satisfactory }\end{array}$ & 10.5 & 19.0 & 23.8 & 35.2 & 11.5 \\
\hline
\end{tabular}




\begin{tabular}{|c|c|c|c|c|c|}
\hline $\begin{array}{l}2.3 \text { My salary in this hotel is fair for my } \\
\text { responsibilities }\end{array}$ & 7.1 & 35.2 & 23.8 & 20.0 & 13.9 \\
\hline $\begin{array}{l}2.4 \text { Benefits provided as a package in this } \\
\text { hotel (e.g. sick leave, maternity \& paternity) } \\
\text { give me stability }\end{array}$ & 25.2 & 46.2 & 19.0 & 6.2 & 3.4 \\
\hline $\begin{array}{l}2.5 \text { My pay in this hotel is not necessarily } \\
\text { subject to organisational performance }\end{array}$ & 10.5 & 30.5 & 33.3 & 19.0 & 6.7 \\
\hline $\begin{array}{l}\text { 2.6 Employee initiative in this hotel is always } \\
\text { compensated }\end{array}$ & 12.9 & 29.5 & 31.0 & 16.6 & 10.0 \\
\hline \multicolumn{6}{|c|}{$\begin{array}{l}\text { Reliability Statistics (compensation), Cronbach's Alpha =.676, } N \text { of Items }=5 \text { (when item } 2.5 \text { in } \\
\text { the Table }- \text { 'pay', is deleted) } \\
\text { Cronbach's Alpha }=.616, N \text { of Items }=6 \text { (when all items in the Table are included) } \\
\text { Valid cases }=210(100 \%), \text { Excluded cases }=0(0 \%), \text { Total }=210\end{array}$} \\
\hline \multicolumn{6}{|l|}{3 Employee development } \\
\hline $\begin{array}{l}3.1 \text { If I do good work in this hotel, I can count } \\
\text { on being promoted }\end{array}$ & 21.9 & 28.6 & 19.5 & 17.6 & 12.4 \\
\hline $\begin{array}{l}3.2 \text { I did not receive extensive customer } \\
\text { service trainingin this hotel }\end{array}$ & 7.1 & 9.5 & 21.9 & 39.0 & 22.5 \\
\hline $\begin{array}{l}3.3 \text { Continuous training is provided in this } \\
\text { hotel }\end{array}$ & 31.4 & 42.9 & 10.0 & 5.7 & 10.0 \\
\hline $\begin{array}{l}3.4 \text { Support for my long term career } \\
\text { development is provided in this hotel }\end{array}$ & 20.0 & 36.2 & 20.0 & 11.9 & 11.9 \\
\hline $\begin{array}{l}3.5 \text { My supervisors in this hotel explain the } \\
\text { key success factors on the job }\end{array}$ & 23.8 & 43.3 & 15.7 & 7.6 & 9.6 \\
\hline $\begin{array}{l}\text { 3.6 This hotel has opportunities for skills } \\
\text { development }\end{array}$ & 32.9 & 33.3 & 12.9 & 10.5 & 10.4 \\
\hline \multicolumn{6}{|c|}{$\begin{array}{l}\text { Reliability Statistics (employee development), Cronbach's Alpha }=.829, \boldsymbol{N} \text { of Items }=\mathbf{6} \\
\text { Valid cases }=210(100 \%), \text { Excluded cases }=0(0 \%), \text { Total }=210\end{array}$} \\
\hline \multicolumn{6}{|l|}{4 Work engagement } \\
\hline $\begin{array}{l}4.1 \text { In my job in this hotel, I have sufficient } \\
\text { opportunities to use my initiative }\end{array}$ & 15.2 & 48.6 & 19.0 & 10.5 & 6.7 \\
\hline $\begin{array}{l}\text { 4.2For a large part I determine how I work in } \\
\text { this hotel }\end{array}$ & 11.9 & 39.5 & 26.2 & 12.4 & 10.0 \\
\hline $\begin{array}{l}\text { 4.3I am not empowered to solve customer } \\
\text { problems in this hotel }\end{array}$ & 6.2 & 13.8 & 20.0 & 42.9 & 17.1 \\
\hline $\begin{array}{l}4.4 \mathrm{I} \text { am not strictly supervised or controlled } \\
\text { in this hotel }\end{array}$ & 8.6 & 23.8 & 21.9 & 25.7 & 20.0 \\
\hline $\begin{array}{l}4.5 \text { I enjoy meeting and serving customers in } \\
\text { this hotel }\end{array}$ & 49.5 & 37.6 & 8.1 & 3.3 & 1.5 \\
\hline $\begin{array}{l}\text { 4.6I am afforded an opportunity to decide } \\
\text { how to do my work from time to time in this } \\
\text { hotel }\end{array}$ & 22.4 & 41.9 & 16.7 & 9.5 & 9.5 \\
\hline \multicolumn{6}{|c|}{$\begin{array}{l}\text { Reliability Statistics (work engagement), Cronbach's Alpha }=.639, \mathbf{N} \text { of Items }=\mathbf{6} \\
\text { Valid cases }=210(100 \%), \text { Excluded cases }=0(0 \%), \text { Total }=210\end{array}$} \\
\hline \multicolumn{6}{|l|}{5 Work relations } \\
\hline $\begin{array}{l}5.1 \text { I have a good working relationship with } \\
\text { my supervisors in this hotel }\end{array}$ & 30.0 & 42.4 & 11.4 & 8.1 & 8.1 \\
\hline $\begin{array}{l}5.2 \text { I work very well with everyone in this } \\
\text { hotel }\end{array}$ & 43.3 & 42.9 & 8.6 & 3.8 & 1.4 \\
\hline $\begin{array}{l}5.3 \text { I enjoy good communications with my } \\
\text { supervisors in this hotel }\end{array}$ & 28.1 & 41.0 & 15.7 & 8.1 & 7.1 \\
\hline $\begin{array}{l}5.4 \text { I enjoy good communications with my } \\
\text { colleagues in this hotel }\end{array}$ & 48.1 & 42.9 & 8.1 & 0.5 & 0.4 \\
\hline $\begin{array}{l}5.5 \text { I think of the workplace as my second } \\
\text { home and my colleagues as my family in this }\end{array}$ & 29.5 & 33.3 & 20.0 & 10.5 & 6.7 \\
\hline
\end{tabular}




\begin{tabular}{|c|c|c|c|c|c|}
\hline \multicolumn{6}{|l|}{ hotel } \\
\hline $\begin{array}{l}5.6 \text { I have good working relationships with } \\
\text { my colleagues in this hotel }\end{array}$ & 41.4 & 43.8 & 12.9 & 1.4 & 0.5 \\
\hline \multicolumn{6}{|c|}{$\begin{array}{l}\text { Reliability Statistics (working relations), Cronbach's Alpha }=\mathbf{8 0 3}, \mathbf{N} \text { of Items }=\mathbf{6} \\
\text { Valid cases }=210(100 \%), \text { Excluded cases }=0(0 \%), \text { Total }=210\end{array}$} \\
\hline \multicolumn{6}{|l|}{6 Working hours } \\
\hline $\begin{array}{l}6.1 \text { My working hours are adequate in this } \\
\text { hotel }\end{array}$ & 17.1 & 51.4 & 17.6 & 7.6 & 6.3 \\
\hline $\begin{array}{l}6.2 \text { My job schedule in this hotel does not } \\
\text { interfere with my family life }\end{array}$ & 11.4 & 36.2 & 22.9 & 18.1 & 11.4 \\
\hline $\begin{array}{l}6.3 \text { In this hotel, I am given enough time to } \\
\text { do what is expected of me in my job }\end{array}$ & 19.0 & 47.6 & 19.5 & 6.7 & 7.2 \\
\hline $\begin{array}{l}\text { 6.4 Working hours in this hotel infringe on } \\
\text { my personal quality time with friends }\end{array}$ & 10.0 & 21.0 & 28.6 & 27.6 & 12.8 \\
\hline $\begin{array}{l}6.5 \text { Long working hours are not a problem to } \\
\text { me }\end{array}$ & 11.4 & 30.0 & 24.8 & 21.0 & 12.8 \\
\hline $\begin{array}{l}\text { 6.6 The hotel's long working hours are } \\
\text { unreasonable }\end{array}$ & 6.2 & 18.6 & 22.4 & 34.3 & 18.5 \\
\hline \multicolumn{6}{|c|}{$\begin{array}{l}\text { Reliability Statistics (working hours), Cronbach's Alpha }=.717, \mathbf{N} \text { of Items }=\mathbf{6} \\
\text { Valid cases }=210(100 \%), \text { Excluded cases }=0(0 \%), \text { Total }=210\end{array}$} \\
\hline
\end{tabular}

These numbers may not be highly satisfactory, however it shows some level of commitment towards the hotels by the respondents and gives hope to the employers that the work conditions in the hotels are not very alarming. Regarding the negative result on 'strict supervision', Cloete and Allen-Payne's (2012) suggested coaching and mentoring would be adequate development plans to be harnessed in hotels over the long-term to develop employees to the level where they will no longer require strict supervision to do their work satisfactorily. Without proper training, employees may not be able to perform their jobs optimally (Ford et al., 2012). Strict supervision can be implemented at the early phase of employment, but not on the long-term, else employees will become demotivated, having someone to 'look over their shoulders' all the time. This study's employees concern on strict supervision can be redirected to employee engagement. Karatepe and Ngeche (2012) advised hotel managers to engage or involve their employees in the hotel operations and decision-making, as engaged employees are known to have high levels of energy, are excited in their job and are mostly absorbed in their work. They posit that work engagement does lead to excellent performance in the workplace.

This study results are similar to Mohsin et al. (2013) finding that long working hours and the accompanying job pressures and stress in hotel employee's personal life have impacts on employees' intention to leave the hotel. The hotel sector is associated with long and antisocial working hours (Davidson \& Wang, 2011). Hwang et al. (2014) posit that some of the common occupational stresses experienced by hotel employees are long working hours and heavy workloads. Davidson and Wang (2011) found that hotel sector employees are often not compensated for their long working hours. This study argues that when employees accept a job in a hotel, they are usually advised that they may have to work long hours and over the weekends. When employees need a job desperately, they are likely to accept whatever is on offer, no matter the conditions attached to it. However those with hospitality education and those who truly want to work in hotels know that this condition exists not only in the hotels but in other businesses operating within the hospitality industry. This study therefore posit that fairness in hotel employment can be achieved if the employee remuneration is linked to the employees working hours and be properly communicated to both part-time and full-time staff so that individuals can clearly observe the impact that longer working hours have on their salary. Problems will however continue to exist if this link is perceived to be unfair among employee clusters, and also where employees are paid differently though they have similar qualifications, and do same work at same period of time.

As earlier reported, fair pay is perceived to improve employee job engagement, and at the same time, decrease job withdrawal (Jung \& Yoon, 2015). Till and Karren (2011) therefore stated that pay satisfaction is arguably a function of the difference between perceived pay level and the employees' perception of how 
much their pay should be. Perceptions of unfair compensation are usually encountered whenthe amount of pay that an employee receives is not aligned to the industry wage for the position which the employee is holding, or when the compensation that an employee receives is considered unfair compared to the employee's responsibilities. In certain cases, there could also be unequal pay between male and female employees, between racial groups or between 'able' and 'disabled' employees. It is therefore imperative that management consider and implementstaff compensation that is based on the nature of work, and also uses performance-related-pay to support a work environment that promotes equity, ownership of responsibilities, and creativity among hotel staff.Nasurdin et al. (2015) finding support the implications of these results that monetary rewards are very relevant to hotel employees because these job is normally associated with low wage and minimal tangible rewards. As Yang et al. (2012), put it, employees who feel that promotion opportunities, fair pay and better working hours are lacking in an organisation, are very likely to withdraw their employment. However, Wu et al. (2013) posited that when employees perceive their salary to be fair, they will make every effort to deliver proper service.

Table 3: Non-parametric correlations among factors $(n=210)$

\begin{tabular}{|c|c|c|c|c|c|c|}
\hline & $\begin{array}{l}\text { Employee } \\
\text { Retention } \\
\text { Factor }\end{array}$ & $\begin{array}{l}\text { Employee } \\
\text { Development } \\
\text { Factor }\end{array}$ & $\begin{array}{l}\text { Work } \\
\text { Engagement } \\
\text { Factor }\end{array}$ & $\begin{array}{l}\text { Work } \\
\text { Relations }\end{array}$ & $\begin{array}{l}\text { Working } \\
\text { Hours }\end{array}$ & $\begin{array}{l}\text { Compensation } \\
\text { (without 2.5) }\end{array}$ \\
\hline $\begin{array}{l}\text { Employee } \\
\text { Retention } \\
\text { Factor }\end{array}$ & $\begin{array}{l}\text { same } \\
\text { factors }\end{array}$ & $* * *$ & $* * *$ & $* * *$ & $* * *$ & $* * *$ \\
\hline $\begin{array}{l}\text { Employee } \\
\text { Development } \\
\text { Factor }\end{array}$ & $* * *$ & same factors & $* * *$ & $* * *$ & $* * *$ & $* * *$ \\
\hline $\begin{array}{l}\text { Work } \\
\text { Engagement } \\
\text { Factor }\end{array}$ & $* * *$ & $* * *$ & same factors & $* * *$ & $* * *$ & $* * *$ \\
\hline $\begin{array}{l}\text { Work } \\
\text { Relations }\end{array}$ & $* * *$ & $* * *$ & $* * *$ & $\begin{array}{l}\text { same } \\
\text { factors }\end{array}$ & $* * *$ & $* * *$ \\
\hline $\begin{array}{l}\text { Working } \\
\text { Hours }\end{array}$ & $* * *$ & $* * *$ & $* * *$ & $* * *$ & $\begin{array}{l}\text { same } \\
\text { factors }\end{array}$ & $* * *$ \\
\hline $\begin{array}{l}\text { Compensation } \\
\text { (without } 2.5 \text { ) }\end{array}$ & $* * *$ & $* * *$ & $* * *$ & $* * *$ & $* * *$ & same factors \\
\hline
\end{tabular}

${ }^{* * *}$ Correlation is significant at the 0.01 level (2-tailed). All p-values $<0.001$. Spearman's Rank correlation coefficient was used as all variables were not normally distributed.

Results in Table 3 show that there exist positive inter-correlations among 'employee retention' factor and other factors that relate to work conditions that support employee retention (compensation, employee development, work engagement, work relations, and working hours). It means therefore that each factor enhance one another, for example when employees perceive that they are receiving adequate development and engagement in their work, they will likely remain in the hotel employment for a long time. Also employees who feel they are being developed adequately also tend to have better work relationships with their co-employees and managers. This research validates previous findings that all these factors need to be carefully managed to attract and retain talented employees. The results of Chi-Square statistics between employee retention and related variables on the one hand, and the employees' socio-demographic variables, on the other hand, show that:

- Immigrant employees agree less than South African employees that 'their salary in the hotel is fair for their responsibility',

- Female employees disagree more than their male counterparts that 'benefits provided as a package in this hotel give them stability',

- Black and Coloured employees agree less than other cultural groups that 'employee initiative in the hotel is always compensated', 
- Coloured employees agree less than other cultural groups that if they do good work in this hotel, they can count on being promoted', 'support for their long term career development is provided in hotel', and 'the hotel's long working hours are unreasonable',

- Black employees agree less than other cultural groups that in their job in the hotel, they have sufficient opportunities to use their initiative', and

- White employees agree more than other cultural groups that 'they are not strictly supervised or controlled'.

It is revealed therefore, that significant numbers of immigrants, females, and Black and Coloured employees perceive they are not fairly compensated. Managers need to take note of this and endeavour to create a working environment that fosters equity, creativity and ownership of responsibilities among hotel employees. We conclude this study and address management implications in the next section.

\section{Conclusion and Management Implication}

The findings of this study are beneficial to hotel employers as they will help them address employee concerns and reduce the high employee turnover costs. A significant number of hotel employees are concerned about strict supervision, long working hours, and unfair salary in hotels, however the majority of the employees have favorable attitude towards hotel employment. More immigrants, females, black and colored employees perceive they are not fairly compensated. This study therefore suggests (a) that employee development plans should focus on coaching and mentorship instead of on strict supervision, (b) that fairness in hotel employment can be achieved if the employee remuneration is linked to the employees working hours and be properly communicated, and (c) that management implement staff compensation that is based on the nature of work, and use performance-related-pay to support a work environment that is non-racial but promotes equity, ownership of responsibilities, and creativity among hotel employees. Further research is encouraged in hotels in other countries of the world to establish cultural comparisons and contrasts among nations or continents, regarding employee retention and its related factors.

\section{References}

AlBattat, A. R., Som, A. P. M. \&Halalat, A. S. (2014). Higher dissatisfaction higher turnover in the hospitality industry. International Journal of Academic Research in Business and Social Science, 4(2), 45-52.

Baum, T. (2012). Human resource management in tourism: a small island perspective. International Journal of Culture, Tourism and Hospitality Research, 6(2), 124-132.

Chen, L. \& Wallace, M. (2011.) Multiskilling of frontline managers in the five star hotel industry in Taiwan. Research and Practice in Human Resource Management, 19(1), 25-29.

Cloete, E. \& Allen-Payne, C. (2012). Human Resource Management: induction and Employment Equity. Pretoria: Van Schaik.

Cortina, J. (1993). What is coefficient alpha? An examination of theory and applications. Journal of Applied Psychology, 78(1), 98-104.

Davidson, M.C.G. \& Wang, Y. (2011). Sustainable labor practices? Hotel human resource managers views on turnover and skill shortages. Journal of Human Resources in Hospitality and Tourism, 10(3), 235-253.

Ezeuduji, I. (2013). Nigerian tourists to South Africa: challenges, expectations and demands. Acta Commercii, 13(1), 1-9.

Ezeuduji, I.0. \& de Jager, K. (2015). Choice of intermediary for leisure travel arrangements. Journal of Economics and Behavioral Studies, 7(5), 65-78.

Ford, R.C., Sturman, M.C. \& Heaton, C.P. (2012). Managing quality service in hospitality: how organisations achieve excellence in the guest experience. New York: Delmar Cengage Learning.

George, D. \& Mallery, P. (2003). SPSS for Windows step by step: A simple guide and reference, 11.0 update (4th Ed.). Boston: Allyn \& Bacon.

Gliem, J. \&Gliem, R. (2003). Calculating, interpreting, and reporting Cronbach's Alpha Reliability Coefficient for Likert-type scales. Midwest Research-to-Practice conference in Adult, continuing, and community Education, the Ohio State University held in Columbus, OH, October 8-10, 2003. 
Hon, A. H. Y., Chan, W. W. H \& Lu, L. (2013). Overcoming work-related stress and promoting employee creativity in hotel industry: the role of task feedback from supervisor. International Journal of Hospitality Management, 33, 416-424.

Hong, E. N.C.,Hao, I.Z., Kumar, R., Ramendran, C. \&Kadiresan, V. (2012). An effectiveness of human resource management practices on employee retention in institute of higher learning: a regression analysis. International Journal of Business Research and Management, 3(2), 60-79.

Hwang, J., Lee, J., Chang, H. \& Kim, S.S. (2014). The impact of occupational stress on employee's turnover intention in the luxury hotel segment. International Journal of Hospitality \& Tourism Administration, 15(1), 60-77.

IBM Corporation. (2016). IBM SPSS Statistics for Windows, Version 24.0. Armonk, NY: IBM Corp.

Jung, H. S \& Yoon, H. H. (2015). Understanding pay satisfaction: the impacts of pay satisfaction on employees' job engagement and withdrawal in deluxe hotel. International Journal of Hospitality Management, 48, $22-26$.

Karatepe, O.M.\&Ngeche, R.N. (2012). Does job embeddedness mediate the effect of work engagement on job outcomes? a study of hotel employees in Cameroon. Journal of Hospitality Marketing and Management, 21(4), 440-461.

Kim, S. S., IM, J. H.\& Wang, J. (2015). The effects of mentor on role stress, job attitude, and turnover intention in the hotel industry. International Journal of Hospitality Management, 48, 68-82.

Kong, H., Cheung, C.\& Song, H. (2012). Determinants and outcome of career competencies: perspectives of hotel managers in China. International Journal of Hospitality Management, 31, 712-719.

Kuria, S., Alice, O. \& Wanderi, P. M. (2012). Assessment of causes of labour turnover in three and five starrated hotels in Kenya. International Journal of Business and Social Science, 3(15), 311-317.

Lam, W. \& Chen, Z. (2012). When I put on my service mask: determinants \& outcomes of emotional labor among hotel service providers according to effective event theory. International Journal of Hospitality Management, 31, 3-11.

Lee, A. P., Teng, H \& Chen, C. (2015). Workplace relationship quality and employee job outcomes in hotel firms. Journal of Human Resources in Hospitality and Tourism, 14(4), 398-422.

McNamara, M., Bohle, P. \& Quinlan, M. (2011). Precarious employment, working hours, work-life conflict and health in hotel work. Applied Ergonomics, 42, 225-232.

Mohanty, S. \& Mohanty, K. (2014). Employee retention: a key driver to the growth of tourism and hospitality in Odisha. International Journal for Innovation Education and Research, 2(12), 94-112.

Mohsin, A., Lengler, J. \& Kumar, B. (2013). Exploring the antecedents of intentions to leave the job: the case of luxury hotel staff. International Journal of Hospitality Management, 35, 48-58.

Nasurdin, A. M., Ahmad, N.H. \& Tan, C.L. (2015). Cultivating service-oriented citizenship behavior among hotel employees: the instrumental roles of training and compensation. Serv Bus, 9, 343-360.

Nunnally, J. C. (1978). Psychometric theory. New York: McGraw-Hill.

O'Neill, J. W. \& Davis, K. (2011). Work stress and well-being in the hotel industry. International Journal of Hospitality Management, 30, 385-390.

Pearlman, D.M. \& Schaffer, J.D. (2013). Labor issues with the hospitality and tourism industry: a study of Louisana's attempted solutions. Journal of Human Resource in Hospitality \& Tourism, 12(3), 217-242.

Permarupan, P.Y., Saufi, R.A. \& Mahmud, R. (2013). The relationship between career development and talent development practices: towards employee quality work life balance. International Journal of Multidisciplinary Thought, 3(2), 463-475.

Solnet, D., Kralj, A. \& Kandampully, J. (2012). Generation Y employees: An examination of work attitude differences. The Journal of Applied Management and Entrepreneurship, 17(3), 37-54.

Tavakol, T. \& Dennick, R. (2011). Making sense of Cronbach's Alpha. International Journal of Medical Education, 2(1), 53-55.

Till, R.E. \& Karren, R. (2011). Organizational justice perceptions and pay level satisfaction. Journal of Managerial Psychology, 26(1), 42-57.

Veal, A. J. (2011). Research methods for leisure and tourism: a practical guide. $4^{\text {th }}$ ed. Pearson: Essex.

Wells, J. E. \& Welty Peachey, J. (2011, June). Voluntary organizational turnover intentions: Do Leadership behavior and satisfaction matter? Paper presented at the annual conference of the North American Society for Sport Management. London, Ontario.

Wu, X., Sturman, M.C. \& Wang, C. (2013). The motivational effects of pay fairness: a longitudinal study in Chinese star-level hotels. Cornell Hospitality Quarterly, 54(2), 185-198. 
Yam, L. \& Raybould, M. (2011). Employee retention: job embeddedness in the hospitality industry. $9^{\text {th }}$ Apac CHRIE Conference. Hospitality and tourism education: from a vision to an icon. Hong Kong. June. Retrieved 20 June 2015, from: http://epublications.bond.edu.au/business_pubs/504

Yang, J., Wan, C. \& Fu, Y. (2012). Qualitative examination of employee turnover and retention strategies in international tourist hotels in Taiwan. International Journal of Hospitality Management, 31, 837-848.

Zopiatis, A., Constanti, P. \& Theocharous, A.L. (2014). Job involvement, commitment, satisfaction and turnover: evidence from hotel employees in Cyprus. Tourism Management, 41, 129-140. 